\title{
REGRESSION MODEL OF VALUES CONSTRUCTION ENTERPRISES IN THE YEARS 2007-2014
}

\author{
[Regresní model hodnot stavebních závodů za období 2007-2014] \\ Miloš Bahenskýn ${ }^{1}$ Bohumil Puchýŕ ${ }^{2}$ \\ ${ }^{1}$ Vysoké Učení Technické v Brně, Ústav soudního inženýrství, Purkyňova 464/118, 61200 Brno \\ Email:milos.bahensky@usi.vutbr.cz \\ ${ }^{2}$ Vysoké Učení Technické v Brně, Fakulta stavební, Rybkova 1, 60200 Brno \\ Email:puchyr.b@fce.vutbr.cz
}

\begin{abstract}
The first goal of the submitted contribution is to determine objectified value of the construction enterprises. For a low objectified boundary value is applied Direct Capitalization Method. The main aim of this contribution is using the model of simple linear regression to express value on the appropriate size of equity in the Czech economy in the years 2007-2014. Research sample ( $\mathrm{N}=35)$ includes medium and large construction enterprises operating in the Czech Republic. The legal form of construction enterprises is Public Limited Company and Private Limited Company. These construction enterprises are valued at eight consecutive years. This resulted in a total of 278 values of construction enterprises. The regression model that includes a total of 278 observations. An integral part of the model of simple linear regression are the assumptions that give the model adequacy. The final regression model can be recommended for expert practice fast, simple, impartial estimate may be used for purposes of business economics. An important part is also a demonstration appropriately selected transformation data series that allows the use of simple linear regression model.
\end{abstract}

Keywords: data transformation, enterprise value, equity, simple linear regression model.

JEL classification: G30, G32, M42

Doručeno redakci: 10.7.2017; Recenzováno: 21.7.2017; 26.7.2017; Schváleno k publikování: 20.9.2017

\section{Úvod}

Problematika oceňování obchodních závodů je obsáhlá nadoborová disciplína, která spadá do oboru soudního inženýrství, ale také např́klad do podnikové ekonomiky. Výsledkem procesu ocenění obchodního závodu je hodnota. Pro zjištění hodnoty obchodních závodů máme $\mathrm{k}$ dispozici hned několik př́stupů a metod, současná praxe ale preferuje př́stup výnosový, jako ten „nejsprávnější“, pokud je předpoklad fungování obchodního závodu do budoucna (tzv. going concern principle). Volbě kategorie hodnoty by měl vždy odpovídat přístup a metoda ocenění.

Analýzou ekonomických extenzivních časových řad se zabývá řada autorů, např. (Sabolovič 2009), ale pokud jde o rešerši dané problematiky, není autorům známa žádná existující extenzivní analýza časové řady stavebních závodů v podmínkách ekonomiky České republiky ani v zahraničí, která řeší závislost mezi vlastním kapitálem a jejich výnosovou hodnotou. Zahraniční srovnání se jeví problematické z důvodu odlišností jednotlivých ekonomik, které mají prímý vliv na výnosovou hodnotu.

Cílem tohoto př́spěvku je sestavit empirický regresní model mezi vysvětlovanou (závislou) proměnnou, tj. hodnotou stavebního závodu a vysvětlující (nezávislou) proměnnou, tj. velikostí vlastního kapitálu za období let 2007-2014. Příspěvek je nosnou částí a výstupem disertační práce na téma: „Závislost hodnoty stavebního závodu na velikosti vlastního kapitálu“. 


\section{Teoretická vymezení pro regresní model}

\section{Zkoumaná entita - stavební závod - obchodní závod stavební produkce (SZ)}

Stavebnictví je dnes bráno jako samostatné odvětví národního hospodářství. Na stavební trh vstupují na jedné straně subjekty, které zastupují stranu poptávky - investoři (napřr. stát, obce, developeři, domácnosti), na straně nabídky pak subjekty, které se tuto poptávku snaží uspokojit, tedy např. dodavatelé, projekční a inženýrské kanceláře, výrobci stavebních hmot atd. Dále zde ještě působí kontrolní orgány, tedy orgány státní správy (Marková 2007).

V rámci klasifikace CZ-NACE stavebnictví (stavební činnosti), definováno v sekci $\mathrm{F}$ (oddíl 41 „Výstavba budov“, oddíl 42 „Inženýrské stavitelství“, oddíl 43 „Specializované stavební činnosti) (Eurostat 2008).

Podle Markové (2007, s. 8) je definován stavební závod jako obchodní závod, který na stavebním trhu vystupuje jako právnická osoba $\mathrm{v}$ roli zhotovitele a dodavatele, jehož hlavní činností je stavební výroba.

\section{Vlastní kapitál (VK) - účetní hodnota na principu historických cen}

Každý obchodní závod z pohledu legislativy je povinen vést účetnictví. Ze zákona o účetnictví vyplývá, že každá podnikatelská jednotka, bez ohledu na právní formu podnikání, je povinna jednou za rok zpracovat účetní závěrku. Podstatou je identifikovat jednak celkový rozsah majetku (aktiv), jednak kapitálu (pasiv), ze kterého byl majetek pořízen.

Vlastní kapitál je standardně uveden v rozvaze na straně pasiv, řádek 68 (ř. $69+73+80+83+87$ ), tedy součtem základního kapitálu, kapitálových fondů, rezervního fondu, nedělitelného fondu a ostatních fondů ze zisku, výsledkem hospodaření z minulých let, výsledkem hospodaření běžného období.

Z hlediska metodiky ocenění obchodních závodů lze na účetní velikost vlastního kapitálu nahlížet jako na netto hodnotu obchodního závodu (majetkovým př́istupem, účetní metodou) $=$ nejjednodušší pohled na hodnotu obchodního závodu.

Vlastní kapitál jakožto účetní hodnota na principu historických cen má v rámci oceňovacího znalectví pouze doplňkovou úlohu (Mařík 2011, s. 324).

\section{Kapitalizované čisté výnosy (KČV), paušální varianta - objektivizovaná hodnota na principu výnosového ocenění}

Paušální varianta metody KČV, založená na kapitalizaci zisku (odpovídá metodě př́mé kapitalizace), je vztažená k minulým výsledkům hospodaření obchodního závodu. Základem pro ocenění je výnosový potenciál $\mathrm{k}$ datu ocenění, který je vyvozován $\mathrm{z}$ minulých výnosů (tj. před datem ocenění obchodního závodu). Cílem je určit tzv. trvale odnímatelný čistý výnos (TČV), který by bylo možno rozdělit, aniž bychom snižovali majetkovou podstatu obchodního závodu, tzn., aby s ním bylo možno i do budoucnosti počítat jako se ziskem trvalým, stabilizovaným. TČV se sestaví z minulých výsledků hospodaření vycházejících z období minimálně 3-5 let k datu ocenění (Mařík 2003, s. 234-236).

Cílem je nalezení co možná nejobjektivnějšího, neutrálního odhadu před odhadem v oceňovací praxi více používaným a preferovaným (ale i více subjektivním) výnosovým př́stupem, tj. ocenění metodami DCF (Sabolovič 2009, s. 83). Metody DCF jsou založeny na plánech do budoucna, a pro sestavení extenzivní časové řady jako podklad pro regresní model se autorům jeví neaplikovatelné. 


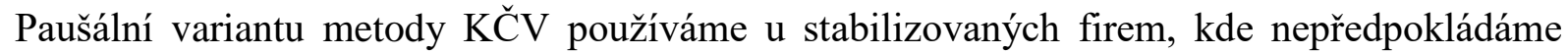
větší dlouhodobý růst obchodního závodu (výsledků hospodaření) a základním předpokladem je stabilizace provozních charakteristik a stabilita budoucích zisků. Výhodou této paušální varianty metody KČV je její jednoduchost. Z hlediska výnosového př́stupu bývá označována, z důvodu neuvažování výnosového potenciálu, jako spodní hranice odhadu hodnoty obchodního závodu (Mařík 2003, s. 235-237).

Vzorce výpočtu TV, $\mathrm{H}_{\mathrm{n}}$ jsou následující (Mařík 2003, s. 234-238):

kde: $T V-$ trvale odnímatelný čistý výnos,

$$
T V=\frac{\sum_{t=1}^{K} q_{t} \times \grave{C} V_{t}}{\sum_{t=1}^{K} q_{t}}
$$

$\check{C} V_{t}-$ minulý upravený čistý výnos v roce t,

$q_{t} \quad$ - váhy (význam čistého výnosu za určitý minulý rok), váha určující důležitost výnosu v roce t pro odhad, váhy, které určují význam čistého výnosu za minulý rok pro odhad budoucího trvale odnímatelného čistého výnosu,

$K \quad$ - počet minulých let zahrnutých do výpočtu.

Pokud se v řadě nachází nějaké extrémní výchylky, je vhodnější je do výpočtu nezahrnovat. Výpočet hodnoty obchodního závodu paušální variantou metody KČV pomocí vzorce pro věčnou rentu je následující:

$$
H_{\mathrm{n}}=\frac{T V}{i_{\mathrm{k}}}
$$

kde: $H_{n}-$ hodnota obchodního závodu (netto),

$T V$ - odhad trvale odnímatelného čistého výnosu pro rok $\mathrm{t}$ prognózy, trvale odnímatelný čistý výnos,

$i_{k} \quad-$ kalkulovaná úroková míra.

\section{Regresní model}

Volba typu regresního modelu - závislost hodnoty stavebního závodu na velikosti vlastního kapitálu (jeden regresor) - jednoduchý, podle typu regresní funkce - zvolen lineární regresní model.

Základní informace $\mathrm{v}$ regresním modelu je rovnice regresní (predikční) přímky. V případě jednoduché lineární regrese je její obecný tvar (Janíček 2014, s. 135-B):

$$
y=b_{0}+b_{1} \times x+e
$$

kde: $y$ - závisle proměnná, resp. výsledek (regresand, outcome) - proměnná, jejíž hodnotu chceme modelem predikovat,

$x \quad$ - nezávisle proměnná, resp. prediktor - proměnná, jejíž hodnota slouží v modelu $\mathrm{k}$ predikci hodnoty $\mathrm{y}$,

$e \quad-$ modelem nevysvětlená chyba. 


\section{Výběr vstupních parametrů do regresního modelu ${ }^{1}$} Stanovení relevantnosti rozsahu výběrového souboru stavebních závodů založené na intervalu spolehlivosti

Nezbytným krokem k zobecnění výsledků je stanovení rozsahu reprezentativního výběrového souboru (resp. chybovosti). Jde o velikost výběru $n$ ze základního souboru s variabilitou danou rozptylem $s^{2}$, která je minimálně potřeba, aby bylo možné se spolehlivostí 100.(1- $\left.\alpha\right) \%$ zabezpečit, že střední hodnota se bude pohybovat $\mathrm{v}$ intervalu (výběrový průměr \pm přesnost odhadu).

Sestavení výběrového souboru stavebních závodů bylo započato rokem 2013, tudíž tento rok byl směrodatný $\mathrm{k}$ určení počtu výběrového souboru stavebních závodů, resp. jeho přesnosti požadované střední hodnoty.

Postup výpočtu je podle následujících vztahů a tabulky (Mrkvička a Petrášková 2006, s. 44):

$$
n=\frac{s^{2} \times t_{\alpha(2), n-1}^{2}}{d^{2}}
$$

kde: $n \quad-$ počet stavebních závodů výběrového souboru,

$s^{2} \quad-$ bodový odhad rozptylu základního souboru,

$d$ - polovina intervalu spolehlivosti střední hodnoty základního souboru (požadovaná přesnost odhadu střední hodnoty),

$t \quad$ - kvantil oboustranného Studentova rozdělení pro n-1 stupňů volnosti a hladinu významnosti $\alpha$.

$$
a=\frac{s \times t_{\alpha(2), n-1}}{\sqrt{n}}
$$

kde: $s \quad-$ bodový odhad směrodatné odchylky,

Tabulka 1: Stanovení minimálního rozsahu výběrového souboru VK roku 2013

\begin{tabular}{|l|l|l|}
\hline Směrodatná odchylka $(s)$ VK $2013(\mathrm{v}$ tis. Kč) & 148056,7 & \\
\hline Rozsah výběrového souboru $(n)$ & 35,0 & \\
\hline Hladina významnosti $(\alpha)$ & 0,05 & \\
\hline Požadovaná přesnost určení střední hodnoty $(d)(\mathrm{v}$ tis. Kč) & 51000 & \\
\hline Počet stavebních závodů $(n)$ & 34,8 & 35 \\
\hline Vypočítaná (skutečná) přesnost určení střední hodnoty $(d)(\mathrm{v}$ tis. Kč) & 50859,2 & \\
\hline
\end{tabular}

Zdroj: Vlastní zpracování

Na základě výše uvedené tabulky lze konstatovat, že při výběru 35-ti stavebních závodů můžeme určit střední hodnotu vlastního kapitálu základního souboru s přesností $\mathrm{d} \pm 51000$ tis. Kč, která platí s pravděpodobností $95 \%$.

Výsledný interval je při počtu 35-ti stavebních závodů [250621 \pm 51000 (tis. Kč)]. V tomto intervalu jsou všechny ostatní střední hodnoty analyzované časové řady 2007-2014).

\section{Vstupní údaje (předpoklady) metodiky k oceňovaným stavebním závodům}

- Geografické a místně př́slušné vymezení základního souboru stavebních závodů - Česká republika.

\footnotetext{
${ }^{1}$ Výběr vstupních parametrů a úvodní část příspěvku koresponduje s příspěvkem 1. autora na téma ANALÝZA ZÁVISLOSTI VLASTNÍHO KAPITÁLU A HODNOTY STAVEBNÍCH ZÁVODŮ V ČESKÉ EKONOMICE V LETECH 2007-2014 v časopise Scientific papers of the University of Pardubice : Series D. Pardubice: Fakulta ekonomicko-správní Univerzity Pardubice, 2017, (39). ISSN 1804-8048.
} 
- Obchodní závody s předmětem své činnosti - Stavebnictví, lhostejno typu stavební produkce z CZ-NACE, sekce F.

- Příslušné podklady pro ocenění stavebních závodů výnosovým přístupem, metodou KČV (rozvaha, výkaz zisků a ztrát, výroční zpráva, zpráva auditora, vymezení převažující činnosti atp.) v období od roku 2005 do roku 2014.

- Náhodný výběr stavebních závodů ze základního souboru - formou generování náhodných čísel (zákonitost statistiky). Podkladem pro stanovení výběrového souboru byl použit časopis českého stavebnictví Stavitel, ročenky TOP 2012, 2013, 2014, 2015.

- Volba stavebních závodů výběrového souboru je omezena právní formou - stavební závody mají právní formu akciových společností (a.s.) a společností s ručením omezeným (s.r.o.).

- Dostupnost údajů o inflaci v ČR.

- Dostupnost výnosnosti dlouhodobých státních obligací v ČR.

\section{Omezení zvolené metodiky ocenění výběrového souboru stavebních závodů}

- Existence stavebního závodu minimálně od roku 2005 do roku 2014.

- Dostupnost př́slušných podkladů pro ocenění od roku 2005 do roku 2014.

- Předpoklad působení stavebního závodu do budoucna (going concern principle).

- Č́itelnost př́islušných podkladů (výročních zpráv a účetních závěrek - problém skenování).

- Neprovozní majetek k datu ocenění u všech stavebních závodů nebyl uvažován.

- Všechny stavební závody mají pro každý rok stejné náklady vlastního kapitálu (stanovené komplexní stavebnicovou metodou).

- Stavební závody, které $\mathrm{v}$ analyzovaném období byly alespoň v jednom roce ve ztrátě, byly $z$ analýzy vyloučeny.

- Z Z analýzy jsou vyloučeny stavební závody v likvidaci.

- Byly vyřazeny stavební závody, u nichž došlo v průběhu analyzované časové řady ke změně účetního období kalendářního roku a k posunu počátku k jinému dni.

- Není známa doba pořízení aktiv, jejich délka životnosti a leasingové podmínky.

- V otázce daní je uvažována neakceptace odložené daně při oceňování stavebního závodu. Veškeré daně byly uvažovány splatné v daném roce analyzovaného období. Daně, resp. daňová sazba ve výběrovém souboru stavebních závodů je kalkulována ve výši platné $\mathrm{k}$ historickému datu ocenění.

\section{Výběr dat}

Databází pro získání dat výběrového souboru stavebních závodů byl zvolen Obchodní rejstř́ik - Justice.cz. Jako počáteční rok časové řady analyzovaných dat byl zvolen rok 2007. Analyzována byla časová řada mezi lety 2007-2014. Paušální varianta metody kapitalizovaných čistých výnosů vyžaduje, aby odhad odnímatelných čistých výnosů byl proveden na základě váženého průměru minimálně třri předcházejících let. Rok 2008 byl proveden na základě váženého průměru čtyř předcházejících let a následující roky 2009-2014 z období pěti předcházejících let. Hodnoty stavebních závodů byly stanoveny pro extenzivní časovou řadu 2007-2014, přičemž předcházející roky 2005-2006 byly využity pro odhad odnímatelných čistých výnosů počátečního roku 2007.

Do výběrového souboru byly zařazeny pouze ty stavební závody, které ve sledovaném období splňovaly výše uvedené vstupní podmínky a omezující předpoklady. Tyto podmínky splňovalo 35 stavebních závodů. Tím bylo získáno celkem 280 hodnot stavebních závodů a př́slušných vlastních kapitálů. 


\section{Abecední seznam výběrového souboru stavebních závodů}

AGROSTAV a.s., BASF STAVEBNÍ HMOTY ČESKÁ REPUBLIKA s.r.o., BETON BROŽ s.r.o., CASTA a.s., ČERMÁK A HRACHOVEC a.s., ČNES DOPRAVNÍ STAVBY a.s., EDIKT a.s., EKOKLIMA a.s., ELEKTRIZACE ŽELEZNIC PRAHA a.s., ENERGIE STAVEBNÍ A BÁŇSKÁ a.s., GJW PRAHA s.r.o., HASIT ŠUMAVSKÉ VÁPENICE A OMÍTKÁRNY s.r.o., CHLÁDEK A TINTĚRA HAVLÍČKŮV BROD a.s., INŽENÝRSKÉ STAVBY BRNO s.r.o., I.KAMENICKÁ STAVEBNÍ A OBCHODNÍ FIRMA s.r.o., KLEMENT a.s., KOMA MODULAR s.r.o., POZEMNÍ STAVITELSTVÍ ZLÍN a.s., PRAGIS a.s., PRVNÍ CHODSKÁ s.r.o., REKO PRAHA a.s., SDS EXMOST s.r.o, SMP CZ, a.s., S.O.K. STAVEBNÍ s.r.o., SPH STAVBY s.r.o., STAVOPROJEKTA STAVEBNÍ FIRMA a.s., STREICHER s.r.o. PLZEŇ, SYNER s.r.o., TENZA a.s., TEPLOTECHNA OSTRAVA a.s., TERMONTA PRAHA a.s., THERM s.r.o., TOMI - REMONT a.s., VW WACHAL a.s., ZIPP Brno s.r.o..

Tabulka 2: Velikost vlastního kapitálu výběrového souboru SZ (v tis. Kč) - pořadí SZ není dle abecedního seznamu

\begin{tabular}{|c|c|c|c|c|c|c|c|c|}
\hline & 2007 & 2008 & 2009 & 2010 & 2011 & 2012 & 2013 & 2014 \\
\hline SZ 1. & 181812 & 241642 & 286059 & 275505 & 317887 & 296253 & 322321 & 359037 \\
\hline SZ 2. & 428582 & 452764 & 504776 & 609642 & 642760 & 638388 & 599510 & 575874 \\
\hline SZ 3. & 321763 & 490519 & 669030 & 592172 & 593392 & 598985 & 580978 & 603913 \\
\hline SZ 4. & 175136 & 194798 & 231491 & 264746 & 283782 & 308326 & 327115 & 346365 \\
\hline SZ 5. & 85981 & 96650 & 94132 & 95652 & 94089 & 123283 & 137836 & 73434 \\
\hline SZ 6. & 253703 & 280469 & 287271 & 283047 & 284738 & 270895 & 268690 & 265716 \\
\hline SZ 7. & 109422 & 104488 & 100540 & 105016 & 105193 & 111644 & 108419 & 107233 \\
\hline SZ 8. & 61631 & 76957 & 96242 & 114177 & 122849 & 133816 & 173172 & 159115 \\
\hline SZ 9. & 124072 & 126402 & 135027 & 154438 & 147265 & 129406 & 131732 & 134409 \\
\hline SZ 10. & 400569 & 391047 & 377503 & 420362 & 424662 & 401599 & 392256 & 386323 \\
\hline SZ 11. & 69038 & 89599 & 137308 & 166731 & 182383 & 217412 & 230043 & 256350 \\
\hline SZ 12. & 116769 & 158553 & 179174 & 196547 & 216298 & 226817 & 176905 & 159208 \\
\hline SZ 13. & 1092766 & 1243541 & 1304895 & 1040705 & 805502 & 800287 & 595474 & 695189 \\
\hline SZ 14. & 29825 & 67263 & 138409 & 155452 & 179020 & 206504 & 213892 & 228218 \\
\hline SZ 15. & 177447 & 196786 & 263815 & 306551 & 306839 & 309005 & 330027 & 353710 \\
\hline SZ 16. & 32353 & 54394 & 114856 & 139046 & 166874 & 195002 & 221151 & 269291 \\
\hline SZ 17. & 45863 & 57526 & 74873 & 120960 & 120973 & 126341 & 128829 & 130916 \\
\hline SZ 18. & 274971 & 339222 & 405721 & 432783 & 440223 & 399639 & 449223 & 430174 \\
\hline SZ 19. & 137387 & 181894 & 238171 & 253790 & 265067 & 273922 & 242355 & 240724 \\
\hline SZ 20. & 42288 & 44340 & 64469 & 69578 & 74508 & 79718 & 83779 & 92505 \\
\hline SZ 21. & 100248 & 133354 & 127118 & 134448 & 162946 & 180829 & 230015 & 90947 \\
\hline SZ 22. & 41828 & 46372 & 52941 & 75549 & 97841 & 131786 & 162103 & 193249 \\
\hline SZ 23. & 149150 & 159461 & 229528 & 231447 & 254008 & 202336 & 162667 & 175708 \\
\hline SZ 24. & 68073 & 74712 & 77231 & 79558 & 92521 & 96626 & 101716 & 107391 \\
\hline SZ 25. & 76389 & 83655 & 80886 & 87917 & 93733 & 106766 & 114677 & 108056 \\
\hline SZ 26. & 63109 & 96533 & 117750 & 134718 & 155133 & 177879 & 206117 & 261705 \\
\hline SZ 27. & 38501 & 45797 & 56468 & 60059 & 63633 & 68723 & 79380 & 95085 \\
\hline SZ 28. & 204482 & 258729 & 316419 & 321457 & 330982 & 341356 & 339552 & 343319 \\
\hline SZ 29. & 570575 & 580992 & 541867 & 479016 & 469785 & 450731 & 445103 & 460079 \\
\hline SZ 30. & 71313 & 73760 & 73730 & 81002 & 84619 & 95250 & 91446 & 94113 \\
\hline SZ 31. & 181807 & 216010 & 278221 & 321659 & 338867 & 359894 & 384289 & 403275 \\
\hline SZ 32. & 84594 & 92543 & 102746 & 110990 & 129228 & 126456 & 126195 & 136504 \\
\hline SZ 33. & 267504 & 261976 & 276771 & 286536 & 282581 & 275165 & 268197 & 190745 \\
\hline SZ 34. & 68297 & 51624 & 63211 & 70994 & 97400 & 100064 & 103047 & 94577 \\
\hline SZ 35. & 94229 & 106026 & 121655 & 154925 & 179091 & 202520 & 243512 & 239468 \\
\hline $\mathbf{A} \mathbf{P}^{2}$ & $\mathbf{1 7 8 3 2 8}$ & 204869 & 234866 & 240776 & 245905 & 250389 & 250621 & 253198 \\
\hline
\end{tabular}

Zdroj: Vlastní zpracování

\footnotetext{
${ }^{2} \mathrm{AP}$ - aritmetický průměr
} 
Tabulka 3: Hodnota SZ výběrového souboru zjištěná výnosovou metodou KČV (v tis. Kč)

\begin{tabular}{|c|c|c|c|c|c|c|c|c|}
\hline & 2007 & 2008 & 2009 & 2010 & 2011 & 2012 & 2013 & 2014 \\
\hline SZ 1. & 18418 & 139363 & 265415 & 399596 & 621832 & 819210 & 640815 & 580997 \\
\hline SZ 2. & 374250 & 613249 & 535242 & 902452 & 1027056 & 1466039 & 989657 & 637041 \\
\hline SZ 3. & 590426 & 687410 & 451891 & 547842 & 555213 & 663118 & 481319 & 395108 \\
\hline SZ 4. & 175167 & 245162 & 174003 & 202821 & 198518 & 272693 & 217533 & 197183 \\
\hline SZ 5. & 48998 & 91805 & 42639 & 47073 & 33381 & 129495 & 203909 & 229329 \\
\hline SZ 6. & 441275 & 669919 & 365836 & 362883 & 315333 & 322228 & 238433 & 202835 \\
\hline SZ 7. & 143087 & 182280 & 81029 & 80602 & 58057 & 83745 & 91848 & 80463 \\
\hline SZ 8. & 130592 & 183992 & 99242 & 139871 & 145009 & 251449 & 268803 & 233530 \\
\hline SZ 9. & 332855 & 422029 & 263773 & 334969 & 290819 & 325763 & 186699 & 123326 \\
\hline SZ 10. & 551482 & 706125 & 361276 & 376130 & 367616 & 429906 & 347644 & 324632 \\
\hline SZ 11. & 132270 & 213812 & 184437 & 215293 & 189300 & 301459 & 204172 & 198561 \\
\hline SZ 12. & 275708 & 369997 & 175822 & 212159 & 238753 & 317870 & 191767 & 125814 \\
\hline SZ 13. & 1233686 & 1754305 & 1002707 & 1163223 & 1088012 & 1255686 & 842011 & 845242 \\
\hline SZ 14. & 22365 & 170138 & 110970 & 140516 & 178610 & 286688 & 181826 & 162664 \\
\hline SZ 15. & 367858 & 449865 & 300972 & 387321 & 302798 & 274138 & 181429 & 224772 \\
\hline SZ 16. & 76720 & 207450 & 111493 & 154529 & 187979 & 286173 & 247293 & 307715 \\
\hline SZ 17. & 53716 & 106039 & 99834 & 261053 & 234232 & 229058 & 112794 & 51967 \\
\hline SZ 18. & 241684 & 358537 & 227406 & 321325 & 400199 & 502090 & 531120 & 529143 \\
\hline SZ 19. & 274945 & 378061 & 230894 & 234680 & 214770 & 234935 & 151229 & 208858 \\
\hline SZ 20. & 47705 & 39957 & 56159 & 49675 & 44193 & 55141 & 38658 & 39021 \\
\hline SZ 21. & 254842 & 455047 & 213992 & 191485 & 183825 & 259917 & 382701 & 318171 \\
\hline SZ 22. & 29605 & 47346 & 32769 & 79280 & 116489 & 235609 & 236323 & 254555 \\
\hline SZ 23. & 213319 & 230627 & 225997 & 334548 & 391997 & 431635 & 306351 & 218109 \\
\hline SZ 24. & 215865 & 229671 & 90747 & 56132 & 49324 & 59053 & 53317 & 47549 \\
\hline SZ 25. & 223467 & 300305 & 150728 & 182207 & 184220 & 246097 & 194151 & 131847 \\
\hline SZ 26. & 241099 & 323926 & 166525 & 163851 & 148720 & 178194 & 181064 & 294003 \\
\hline SZ 27. & 79744 & 100253 & 61337 & 55878 & 46330 & 61213 & 61950 & 89217 \\
\hline SZ 28. & 483441 & 732746 & 449264 & 407001 & 315150 & 310207 & 149280 & 85895 \\
\hline SZ 29. & 599008 & 826647 & 434954 & 394004 & 299258 & 375297 & 237251 & 224668 \\
\hline SZ 30. & 89271 & 122875 & 73090 & 93934 & 65549 & 83724 & 55935 & 48821 \\
\hline SZ 31. & 110694 & 218265 & 188531 & 266337 & 256460 & 308087 & 237180 & 189962 \\
\hline SZ 32. & 99271 & 212032 & 174666 & 187318 & 228875 & 288196 & 176647 & 157881 \\
\hline SZ 33. & 33728 & 55211 & 63980 & 186888 & 264509 & 412807 & 339712 & 340085 \\
\hline SZ 34. & 116797 & 200090 & 111664 & 108266 & 137238 & 146814 & 89793 & 57743 \\
\hline SZ 35. & 56961 & 60597 & 32222 & 23093 & 60472 & 150402 & 152791 & 141087 \\
\hline AP & 239438 & 345861 & 217472 & 264692 & 269717 & 344404 & 262955 & 237080 \\
\hline
\end{tabular}

Zdroj: Vlastní zpracování

V důsledku zvoleného typu modelu je vhodné, resp. nutné přistoupit $\mathrm{k}$ transformaci jak nezávisle proměnné veličiny $\mathrm{VK}$, tak i závisle proměnné veličiny KČV. Vhodně zvolená transformace totiž velmi často vede $\mathrm{k}$ nápravě normality rozdělení dat. Pokud se povede vhodnou transformaci nalézt, můžeme data vyhodnotit klasickými metodami statistické analýzy, jež vyžadují splnění předpokladu normality.

Nejprve je přistoupeno k transformaci nezávisle proměnné veličiny VK. Vzhledem k povaze dat se jeví nejprve jako adekvátní transformace druhé odmocniny nezávisle proměnné veličiny $\mathrm{VK}\left(\mathrm{VK}^{\wedge} 0,5\right)$. $\mathrm{S}$ takto transformovanou nezávisle proměnnou veličinou $\mathrm{VK}^{\wedge} 0,5$ je následně přistoupeno k Box-Coxově transformaci dle vztahů (6) resp. (7) (Hintze 2007), která

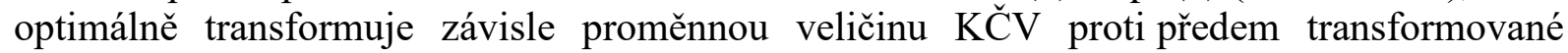
nezávisle proměnné veličině $\mathrm{VK}^{\wedge} 0,5$, jak uvádí Tab. 4. Tuto metodu uveřejnili v roce $1964 \mathrm{G}$. E. P. Box a D. R. Cox pro určení mocninné transformace vysvětlované proměnné, jejímž hlavním cílem je dosažení homoskedasticity rozptylu chybové složky s vedlejším efektem nápravy nenormality. 
Box-Coxova transformace spočívá $\mathrm{v}$ odhadech parametrů mocninné transformace lambda $\lambda$, rozptylu $\sigma^{2}$ a regresních parametrů $\beta$, které přibližují rozdělení transformovaných dat co nejblíže k normálnímu rozdělení. Transformace hledá nejlepší hodnotu lambda $\lambda$ v rozsahu od -2 do +2 .

Ani tato metoda transformace nezaručuje následnou normalitu dat. Po každé transformaci je nutné provést kontrolu normality bud' pomocí numerických testů, nebo diagnostickými grafy.

kde: $Z-$ Box-Cox transformace,

$$
Z=(Y+\delta)^{\lambda}
$$

$Y \quad$ - závisle proměnná veličina,

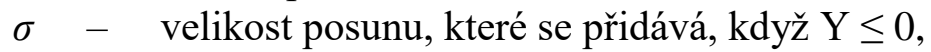

$\lambda-$ exponent (power).

Když je $\lambda=0$, je výše uvedený vzorec (6) nahrazen vzorcem (7).

$$
Z=\ln (Y+\delta)
$$

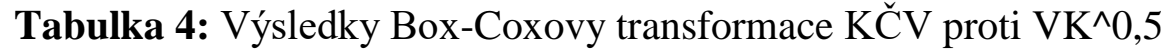

\begin{tabular}{|l|l|}
\hline Velikost posunu, který se př̀idává, když $\mathbf{Y} \leq \mathbf{0}(\boldsymbol{\sigma})$ & Exponent (power) $(\lambda)$ \\
\hline 0,00 & 0,32 \\
\hline
\end{tabular}

Zdroj: Vlastní výpočty v NCSS 2011

V dalším kroku je udělán test na identifikaci odlehlých hodnot (tzv. outliers). K tomu je využito Grubbsova testu (parametrický test), kterým lze extrémní hodnoty vyloučit. Grubbsův test se používá pro větší výběry $(\mathrm{n}>25)$. Takto je postupováno dle vztahu (Blischke, Karim and Murthy 2011, s. 232).

$$
G=\frac{\max _{i=1, \ldots n}\left|Y_{i}-\bar{Y}\right|}{s}
$$

kde: $G-$ hodnota Grubssovy statistiky,

$\bar{Y} \quad$ - výběrový průměr datových řad,

$s \quad-\quad$ směrodatná odchylka výběru datových řad.

$\mathrm{Z}$ provedeného Grubbsova testu pro 280 transformovaných hodnot $\left(\mathrm{VK}^{\wedge} 0,5\right.$ a $\left.\mathrm{KC} \mathrm{C}^{\wedge} 0,32\right)$ datová řada $\mathrm{VK}^{\wedge} 0,5$ testem neprošla. Nad kritickou hodnotou byly testem zjišsěny 2 hodnoty, 1115,142 (1243541 VK) a 1142,320 (1304895 VK). Tyto hodnoty jsou z výběrového souboru vyřazeny a dle výše uvedeného postupu je opět přistoupeno $k$ testu.

\begin{tabular}{|c|c|c|c|c|}
\hline Datová řada & $\mathbf{G}$ & p-hodnota & Alfa & Výsledek testu \\
\hline $\mathrm{VK}^{\wedge} 0,5$ (278 hodnot) & $\begin{array}{l}\text { 3,683 (pozorovaná) } \\
\text { 3,702 (kritická) }\end{array}$ & 0,054 & 0,05 & $\begin{array}{l}\mathrm{H}_{0} \\
\text { nezamítáme }\end{array}$ \\
\hline $\mathrm{KČV}^{\wedge} 0,32$ (278 hodnot) & $\begin{array}{l}\text { 3,263 (pozorovaná) } \\
\text { 3,702 (kritická) }\end{array}$ & 0,277 & 0,05 & $\begin{array}{l}\mathrm{H}_{0} \\
\text { nezamítáme }\end{array}$ \\
\hline
\end{tabular}

Interpretace testu: hypotéza $\mathrm{H}_{0}-\mathrm{v}$ datové řadě nejsou odlehlé body.

Tabulka 5: Grubbsova statistika odlehlých bodů

Zdroj: Vlastní zpracování v XLStat 2015 


\section{Konstrukce regresního modelu}

Rovnice př́mky lineárního regresního modelu závislosti transformovaných veličin $K C \check{V} V^{\wedge} 0,32$ na $\mathrm{VK}^{\wedge} 0,5$ za použití celkem 278 pozorování se stanoví takto:

Rovnice modelu: $\mathrm{KC \check {V }} \mathrm{V}^{\wedge} 0,32=22,75+6,30 \mathrm{E}-02 * \mathrm{VK}^{\wedge} 0,5$

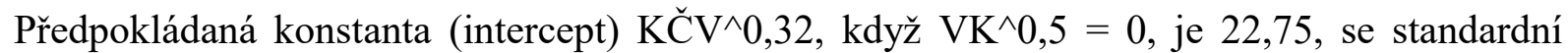
chybou 1,4651. Sklon prímky (slope), resp. odhadovaná změna $K C \check{C} V^{\wedge} 0,32$ na jednotku změny $\mathrm{VK}^{\wedge} 0,5$ je 0,0630 se standardní chybou 0,0031 . Hodnota indexu determinace $\left(\mathrm{R}^{2}\right)$ mezi

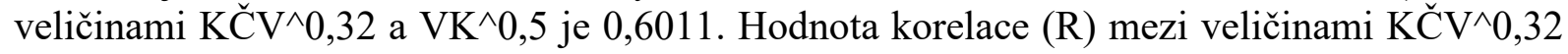
a $\mathrm{VK}^{\wedge} 0,5$ je 0,775 .

Předpokládaný sklon přímky je 0,0630 , prričemž spodní hranice $95,0 \%$ intervalu spolehlivosti je 0,0569 a horní hranice $95,0 \%$ intervalu spolehlivosti je 0,0691 .

Předpokládaná konstanta (intercept) je 22,75, přičemž spodní hranice $95,0 \%$ intervalu spolehlivosti je 19,8648 a horní hranice 95,0\% intervalu spolehlivosti je 25,6333.

Pro model platí, že $0,6011(60,11 \%)$ variability $K C \check{C} V^{\wedge} 0,32$ je vysvětleno $\mathrm{VK}^{\wedge} 0,5$. Zbývající část variability zůstává $\mathrm{v}$ modelu nevysvětlena (možno řešit dalšími vysvětlujícími proměnnými).

Na základě koeficientu korelace $R=0,775$, resp. indexu determinace $R^{2}=0,6011$, lze považovat danou závislost za silnou, a tedy dobře vystiženou použitým regresním modelem (model je dobře navržený).

Tabulka 6: ANOVA modelu $\mathrm{KC}^{\mathrm{C}} \mathrm{V}^{\wedge} 0,32=22,75+6,30 \mathrm{E}-02 * \mathrm{VK}^{\wedge} 0,5$

\begin{tabular}{|l|l|l|l|l|l|}
\hline Proměnná & DF & Součet čtverců & Průměr čtverců & F & Pr $>$ F \\
\hline VK^ $\mathbf{0 , 5}$ & 1 & 29178,866 & 29178,866 & 415,826 & $<0,0001$ \\
\hline Chyba & 276 & 19367,169 & 70,171 & & \\
\hline Správně & 277 & 48546,035 & & & \\
\hline
\end{tabular}

Zdroj: Vlastní zpracování v XLStat 2015

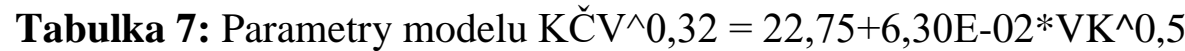

\begin{tabular}{|l|l|l|l|l|l|l|}
\hline Zdroj & Hodnota & $\begin{array}{l}\text { Standardní } \\
\text { chyba }\end{array}$ & $\mathbf{T}$ & Pr $>|\mathbf{t}|$ & $\begin{array}{l}\text { DoIní hranice } \\
(\mathbf{9 5 \% )}\end{array}$ & $\begin{array}{l}\text { Horní hranice } \\
(\mathbf{9 5 \% )}\end{array}$ \\
\hline Intercept & 22,749 & 1,465 & 15,527 & $<0,0001$ & 19,865 & 25,633 \\
\hline VK^ $\mathbf{0 , 5}$ & 0,063 & 0,003 & 20,392 & $<0,0001$ & 0,057 & 0,069 \\
\hline
\end{tabular}

Zdroj: Vlastní zpracování v XLStat 2015

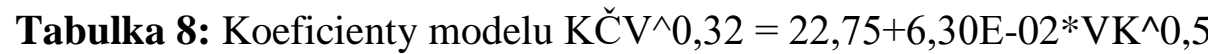

\begin{tabular}{|l|l|l|l|l|l|l|}
\hline Zdroj & Hodnota & $\begin{array}{l}\text { Standardní } \\
\text { chyba }\end{array}$ & $\mathbf{T}$ & $\mathbf{P r}>|\mathbf{t}|$ & $\begin{array}{l}\text { Dolní hranice } \\
(\mathbf{9 5 \% )}\end{array}$ & $\begin{array}{l}\text { Horní hranice } \\
(\mathbf{9 5 \%})\end{array}$ \\
\hline VK$^{\wedge} \mathbf{0 , 5}$ & 0,775 & 0,038 & 20,392 & $<0,0001$ & 0,700 & 0,850 \\
\hline
\end{tabular}

Zdroj: Vlastní zpracování v XLStat 2015

Na základě výše uvedených popisných statistik modelu (celkový F-test i všechny t-testy jsou statisticky významné), výsledný lineární regresní model se dá považovat za vhodný

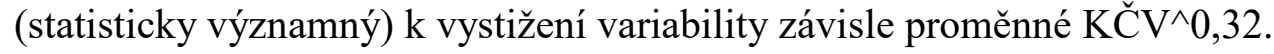


Obrázek 1: Grafické znázornění modelu $\mathrm{KČ}^{\wedge} 0,32=22,75+6,30 \mathrm{E}-02 * \mathrm{VK}^{\wedge} 0,5$

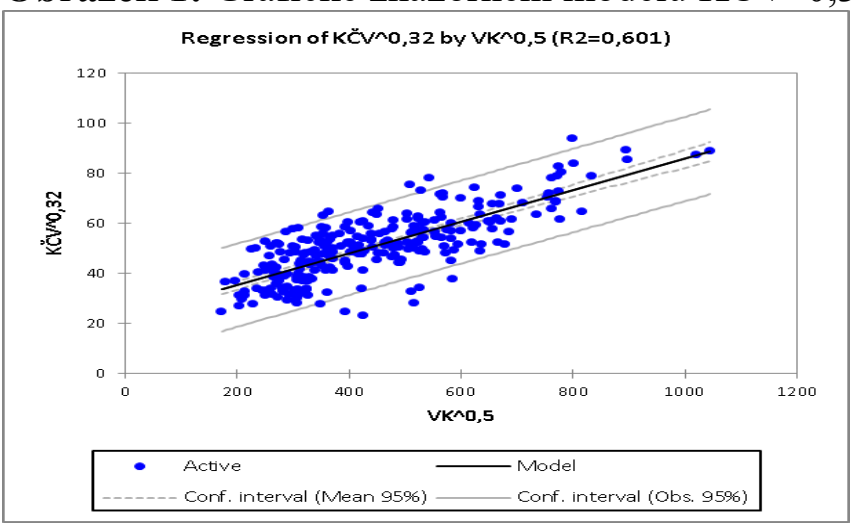

Zdroj: Vlastní zpracování v XLStat 2015

Využití modelu se jeví adekvátní vintervalu [VK^0,5=172,70 - (VK=29825), VK^0,5=1045,35 - $\quad(\mathrm{VK}=1092766]$ tis. Kč pro stavební závody s předpokladem going concern principle.

\section{Ekonometrická verifikace modelu $K \mathrm{KC}^{\wedge} \mathrm{V}^{\wedge} 0,32=22,75+6,30 \mathrm{E}-02 * \mathrm{VK}^{\wedge} 0,5$ Předpoklad normality dat (závisle i nezávisle proměnné)}

Interpretace testi̊ normality: hypotéza $\mathrm{H}_{0}$ - proměnná je z normálního rozdělení.

Tabulka 9: Testy normality nezávisle proměnné $\mathrm{VK}^{\wedge} 0,5$

\begin{tabular}{|l|l|l|l|l|}
\hline Test & Hodnota testu & p-hodnota & Alfa & Výsledek testu \\
\hline Shapiro-Wilkův & $\mathrm{Wn}=0,945$ & $<0,0001$ & 0,05 & $\mathrm{H}_{0}$ zamítáme \\
\hline Anderson-Darlingův & $\mathrm{AD}=4,166$ & $<0,0001$ & 0,05 & $\mathrm{H}_{0}$ zamítáme \\
\hline Lillieforsovův & $\begin{array}{l}\mathrm{D}=0,111 \\
\mathrm{D}(\text { standard })=1,848\end{array}$ & $<0,0001$ & 0,05 & $\mathrm{H}_{0}$ zamítáme \\
\hline Jarque-Berův & $\begin{array}{l}\mathrm{JB}=35,370 \\
\mathrm{JB}(\text { kritická h. })=5,991 \\
\mathrm{DF}=2\end{array}$ & $<0,0001$ & 0,05 & $\mathrm{H}_{0}$ zamítáme \\
\hline
\end{tabular}

Zdroj: Vlastní zpracování v XLStat 2015

Tabulka 10: Testy normality závisle proměnné $K \check{C} V^{\wedge} 0,32$

\begin{tabular}{|l|l|l|l|l|}
\hline Test & Hodnota testu & p-hodnota & Alfa & Výsledek testu \\
\hline Shapiro-Wilkův & $\mathrm{Wn}=0,979$ & $<0,000$ & 0,05 & $\mathrm{H}_{0}$ zamítáme \\
\hline Anderson-Darlingův & $\mathrm{AD}=1,258$ & $<0,003$ & 0,05 & $\mathrm{H}_{0}$ zamítáme \\
\hline Lillieforsovův & $\begin{array}{l}\mathrm{D}=0,048 \\
\mathrm{D}(\text { standard })=0,805\end{array}$ & 0,119 & 0,05 & $\mathrm{H}_{0}$ nezamítáme \\
\hline Jarque-Berův & $\begin{array}{l}\mathrm{JB}=10,323 \\
\mathrm{JB}(\text { kritická h.) }=5,991 \\
\mathrm{DF}=2\end{array}$ & 0,006 & 0,05 & $\mathrm{H}_{0}$ zamítáme \\
\hline
\end{tabular}

Zdroj: Vlastní zpracování v XLStat 2015

Výsledky numerických testů po transformaci VK na $\mathrm{VK}^{\wedge} 0,5$ a $\mathrm{z}$ KČV Box-Coxovou transformací na $K \check{C}^{\wedge} 0,32$ (i po odebrání dvou pozorování označených testy jako odlehlé hodnoty), presto testy neprokázaly normalitu dat. K těmto výsledkům je však nutno přistupovat $\mathrm{s}$ jistou rezervou. Pokud je datový soubor zpravidla $\mathrm{n}>30$ (v tomto př́padě $\mathrm{n}=278$ ) a numerické testy nám na obvyklých hladinách významnosti zamítnou nulovou hypotézu o normalitě dat, (numerické testy jsou na lehké porušení normality s rostoucím n 
citlivé), pak lze normalitu dat připouštět na základě diagnostických grafů normality, které po transformaci ukazují pouze lehké porušení normality dat.

Další oporou pro lehké porušení normality dat může být centrální limitní teorém (Hendl 2004, s. 37-59), který říká, že porušení normality dat ve velkých výběrových souborech nemá př́liš vážné následky. Máme-li tedy dostatečně velký vzorek (n=278 pozorování takový je), lehké porušení normality nemusí být problém $\mathrm{z}$ důvodů platnosti tohoto centrálního limitního teorému. Z výše uvedeného lze vyvodit, že:

$\mathrm{U}$ transformované nezávisle proměnné veličiny $\mathrm{VK}^{\wedge} 0,5, \mathrm{i} \mathrm{u}$ závisle proměnné veličiny

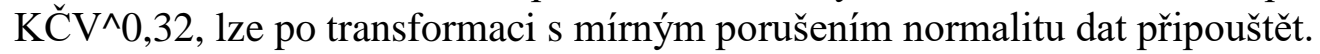

\section{Autokorelace reziduí}

Tabulka 11: Durbin-Watsonova statistika autokorelace reziduí

\begin{tabular}{|l|l|l|l|l|}
\hline Parametr & Hodnota testu & P-hodnota & Alfa & Výsledek testu \\
\hline Durbin-Watsonova statistika & $\mathrm{d}=1,806$ & 0,053 & 0,05 & $\mathrm{H}_{0}$ nezamítáme \\
\hline
\end{tabular}

Zdroj: Vlastní zpracování v XLStat 2015

Z výsledku DW-testu je patrné, že na základě hodnoty 1,806 nelze zamítnout nulovou hypotézu o neexistenci autokorelace $\mathrm{H}_{0}$ na hladině významnosti $\alpha=0,05$.

Předpoklad neexistence autokorelace rozptylu náhodné složky modelu nezbytný pro jednoduchý lineární regresní model metodou MNČ byl pomocí testu DW-statistiky potvrzen.

\section{Předpoklad homoskedascity lineárního regresního modelu}

Tabulka 12: Výsledky Whiteova testu heteroskedascity

\begin{tabular}{|l|l|l|l|l|l|}
\hline LM (Naměřená hodnoty) & LM (Kritická hodnota) & DF & p-hodnota & Alfa & Výsledek testu \\
\hline 1,682 & 5,991 & 2 & 0,431 & 0,05 & $H_{0}$ nezamítáme \\
\hline
\end{tabular}

Zdroj: Vlastní zpracování v XLStat 2015

Z odvozené hodnoty $(0,431>\alpha=0,05)$ nelze zamítnout nulovou hypotézu o homoskedascitě reziduí. Lze tedy na základě tohoto testu konstatovat, že rezidua mají konstantní rozptyl.

Tabulka 13: Výsledky Breusch-Paganova testu heteroskedascity

\begin{tabular}{|l|l|l|l|l|l|}
\hline LM (Naměřená hodnoty) & LM (Kritická hodnota) & DF & p-hodnota & Alfa & Výsledek testu \\
\hline 0,062 & 3,841 & 1 & 0,803 & 0,05 & $H_{0}$ nezamítáme \\
\hline
\end{tabular}

Zdroj: Vlastní zpracování v XLStat 2015

Obdobně jako u Whiteova testu, i u Breusch-Paganova testu z odvozené hodnoty $(0,803>\alpha=0,05)$ nelze zamítnout nulovou hypotézu o homoskedascitě reziduí. Lze tedy i na základě tohoto testu konstatovat, že rezidua mají konstantní rozptyl. Předpoklad homoskedascity rozptylu náhodné složky modelu nezbytný pro jednoduchý lineární regresní model metodou MNČ byl pomocí testů heteroskedascity (Whiteův i Breusch-Paganův) potvrzen. 


\section{Předpoklad normality reziduí lineárního regresního modelu}

Tabulka 14: Testy normality reziduí

\begin{tabular}{|l|l|l|l|l|}
\hline Test & Hodnota testu & p-hodnota & Alfa & Výsledek testu \\
\hline Shapiro-Wilkův & Wn $=0,992$ & 0,113 & 0,05 & $\mathrm{H}_{0}$ nezamítáme \\
\hline Anderson-Darlingův & $\mathrm{AD}=0,396$ & 0,368 & 0,05 & $\mathrm{H}_{0}$ nezamítáme \\
\hline Lillieforsovův & $\begin{array}{l}\mathrm{D}=0,032 \\
\mathrm{D}(\text { standard })=0,534\end{array}$ & 0,696 & 0,05 & $\mathrm{H}_{0}$ nezamítáme \\
\hline Jarque-Berův & $\begin{array}{l}\mathrm{JB}=2,165 \\
\mathrm{JB}(\text { kritická h. })=5,991 \\
\mathrm{DF}=2\end{array}$ & 0,339 & 0,05 & H0 nezamítáme \\
\hline
\end{tabular}

Zdroj: Vlastní zpracování v XLStat 2015

Ze všech provedených testů normality reziduí vyplývá, že rezidua mají normální rozdělení, tj. nulovou střední hodnotu a konstantní rozptyl na hladině významnosti $\alpha=0,05$.

Předpoklad normality reziduí nezbytný pro lineární regresní model metodou MNČ byl za pomocí všech výše uvedených testů potvrzen.

\section{Závěr}

Cílem př́íspěvku bylo sestavit empirický lineární regresní model hodnoty stavebního závodu na velikosti vlastního kapitálu v podmínkách české ekonomiky v letech 2007-2014. Výběrový soubor $(\mathrm{n}=35)$ zahrnuje střední a velké stavební závody s právní formou akciových společností a společností s ručením omezeným. Takto bylo získáno oceněním 278 hodnot stavebních závodů metodou KČV, paušální variantou a z účetnictví stejný počet hodnot vlastních kapitálů. Regresní model tak obsahuje celkem 278 pozorování. Nedílnou součástí modelu lineární regrese jsou předpoklady (normalita proměnných, statistická významnost a správný návrh modelu, nepř́tomnost autokorelace reziduí, homoskedascita reziduí, normalita reziduí, které dávají modelu adekvátnost. Tyto byly všechny splněny.

Za další dílčí cíl příspěvku lze považovat analýzu datového souboru stavebních závodů, který dosud nebyl tímto způsobem zpracován a objasnění některých otázek o závislosti vysvětlované proměnné na zvolené vysvětlující proměnné.

Významnou částí je i ukázka vhodně zvolené transformace datových řad, která umožňuje použití modelu jednoduché lineární regrese.

Za předpokladu, že stavební závod má vlastní kapitál z intervalu [29825, 1092766] tis. Kč a je prosperující (going concern principle), lze výsledný regresní model použít:

1. V praxi znalce nebo odhadce pro doplňkový, rychlý, jednoduchý a nestranný odhad.

2. V oblasti managementu pro zjištění efektivnosti řízení stavebního závodu s ohledem na vývoj výnosové hodnoty v čase.

Podnětem pro další výzkum může být rozšiřrení výběrového vzorku stavebních závodů, resp. rozšíření intervalu velikosti vlastních kapitálů, pokračovat v analýze dalšího časového období. Dalším podnětem pro výzkum může být přidání další vysvětlující proměnné, vhodnou se jeví např. cizí kapitál z důvodu odlišné zadluženosti závodů napříč odvětví stavebnictví. Tato nově přidaná vysvětlující proměnná by mohla regresní model ještě více zpřesnit. 


\section{Literatura}

[1] BAHENSKÝ, M., 2017. Analýza závislosti vlastního kapitálu a hodnoty stavebních závodů v české ekonomice v letech 2007-2014. Scientific Papers of the University of Pardubice, Series D, 2017, roč. 24, č. 39, s. 5-15. ISSN: 1804-8048.

[2] BLISCHKE, W. R., M. R. KARIM and D. N. P. MURTHY, 2011. Warranty data collection and analysis. New York: Springer Verlag. ISBN 978-0-85729-647-4.

[3] Eurostat, 2008. NACE rev.2 Statistical classification of economic activities in the European Community. In: EUROSTAT Methodologies and working papers. [online]. Luxembourg, Office for Official Publications of the European Communities. Dostupné na: World Wide Web: http://epp.eurostat.ec.europa.

eu/cache/ITY_OFFPUB/KS-RA-07-015/EN/KS-RA-07-015-EN. PDF. [cit. 2016-0823].

[4] HENDL, J., 2004. Přehled statistických metod: analýza a metaanalýza dat. Praha: Portál. ISBN 80-7178-820-1.

[5] HINTZE, J., 2007. NCSS, LLC, Kaysville, Utah, USA. Available at: http:// www.ncss.com

[6] JANÍČEK, P., 2014. Systémová metodologie: brána do řě̌ení problémů. Vyd. 1. Brno: Akademické nakladatelství CERM. 1 sv. (různé stránkování) : il. ISBN 978-80-7204887-8.

[7] MARKOVÁ, L., 2007. Stavební podnik. Studijní opora. 1. vydání. Brno: VUT v Brně, FAST.

[8] MAŘÍK, M., 2003. Metody oceňování podniku: proces ocenění - základní metody a postupy 1. uprav. a rozš. vyd., Praha: EKOPRESS. ISBN 80-86119-57-2.

[9] MAŘÍK, M., 2011. Metody oceňováni podniku: proces ocenění - základní metody a postupy 3. uprav. a rozš. vyd., Praha: EKOPRESS. ISBN 978-80-86929-67-5.

[10] MRKVIČKA, T. a V. PETRÁŠKOVÁ, 2006. Úvod do statistiky. 1. vyd, česky, Jihočeská univerzita, České Budějovice, 146 stran, ISBN: 80-7040-894-4.

[11] SABOLOVIČ, M., 2009. Oceňování podniku. Disertační práce. Brno: MZLU v Brně. Školitel: prof. Ing. Iva Živělová, CSc. 